\title{
THE PERSPECTIVE OF STUDENTS ON DRIVERS AND BENEFITS OF BUILDING INFORMATION MODELLING INCORPORATION INTO QUANTITY SURVEYING PROFESSION IN KLANG VALLEY MALAYSIA
} \author{
and Siaw-Chuing LoO4 \\ ${ }^{1}$ Lee Kong Chian Faculty of Engineering and Science, Universiti Tunku Abdul Rahman, Kajang, Malaysia \\ 2 Faculty of Technology Management and Business, Universiti Tun Hussein Onn Malaysia, Batu Pahat, Malaysia \\ ${ }^{3}$ Faculty of Engineering, Built Environment and Information Technology, SEGi University, Petaling Jaya, Malaysia \\ ${ }^{4}$ Faculty of Built Environment, Universiti Malaya, Kuala Lumpur, Malaysia
}

Chai-Chai Lim, Tien-Choon Toh ${ }^{1 *}$, Yoke-Lian Lew ${ }^{1}$, Chin-Xian Lau ${ }^{1}$, Kai-Chen Goh², Md Asrul Nasid Masrom², Nadzirah Zainordin³,

ABSTRACT - Building Information Modelling (BIM) is a very useful tool that facilitates architecture, engineering and construction (AEC) professionals and stakeholders in planning, designing and constructing the buildings through 3D models. BIM can be widened to building operations and data storage which can be accessible by owners and others. Such data help owners and stakeholders to generate results according to the information gained through BIM models. The objectives of this study were to identify the perspective of students on drivers of BIM incorporation into the quantity surveying profession and to identify the perspective of students on benefits of BIM incorporation into the quantity surveying profession. A questionnaire survey was carried out to gain the students' perspective on drivers and benefits of BIM incorporation into the quantity surveying profession in Klang Valley, Malaysia. Specifically, this study investigated twelve drivers and fourteen benefits of BIM incorporation into the quantity surveying profession. The top three drivers were improving the capacity to provide whole-life value to the client, desire for innovation to remain competitive and strong support from university management and industry. The top three benefits were BIM provides fast, effective and efficient quantity take-off and cost estimation, time savings in the preparation of estimating cost and improved visualization for better understanding of designs for measurement and minimise omissions. For future research, it is recommended that the study be replicated at other regions so that a clearer view of this topic can be obtained. Besides, qualitative research methods could be used in identifying other drivers and benefits not covered in this study. By answering the questions in the survey form, the students were able to gain some knowledge on $\mathrm{BIM}$ and its importance to the quantity surveying profession. Also, it would be interesting to include industrial practitioners in this kind of study, allowing comparisons of the results between academia and industry at a later stage. Nonetheless, this study benefited the undergraduate students pursuing the Bachelor of Science (Hons) Quantity Surveying programme, universities, colleges and other institutions that offered the quantity surveying programmes at various levels and quantity surveyors working in the construction industry by exposing them to a comprehensive list of drivers and benefits of BIM incorporation into quantity surveying profession. In a way, this study helped promoted BIM and its implementation in the field of quantity surveying in Klang Valley, Malaysia.
ARTICLE HISTORY

Received: 23-6-2020

Accepted: 1-9-2020

\section{KEYWORDS}

Perspective of students;

Drivers and benefits;

Building information

modelling;

Quantity surveying

profession;

Klang Valley Malaysia

\section{INTRODUCTION}

Construction industry is booming towards modernization. ICT act as a vital role in construction industry revolution. BIM implementation became largely recognized among the architecture, engineering and construction (AEC) industry. BIM able to be adopted in design process for the purpose of producing a high standard of picture for more complicated designs. Apart from that, BIM can be used to anticipate issues and coordination among several contractors and as a path to produce construction documents and process that will be carry out throughout the physical process. It is a good technique to conduct few jobs at the same time or while the programmes are compressed.

BIM is a modern technology and method which offers AEC experts the instruments and vision for producing a better plan, design, create and administer buildings and infrastructure. BIM was also described as a technology constitute of items expressing a number of aspects of a project and information pertaining to each item (Harrison and Thurnell, 2015).

Past research revealed the use of BIM techniques in several developing nations around the globe including The Netherlands, Singapore, USA, New Zealand, Australia, Hong Kong and UK (Isikdag and Underwood, 2010; Wong, Wong and Nadeem, 2011) accompanied of outstanding consequences, notwithstanding several difficulties for BIM employment. The advantages of BIM adoption as well as its performances towards sustainability within the construction industry and the most significant merits were observed which are the standard and efficiency of the project can be increased and the potential to imitate building performances can also be strengthen (Olawumi and Chan, 2018). Moreover, 
Ghaffarianhoseini, et al. (2017) studied the present advantages accompanied by the BIM adoption as well as identified the industry stakeholders does not perfectly exploit the ultimately advantages of the BIM. Besides, Goucher and Thurairajah (2012) found that the benefits and the possible difficulties in the implementation of BIM features for cost consultant. Furthermore, there are studies indicated the fully BIM technologies implementation in all disciplines (Olatunji, Sher and $\mathrm{Gu}, 2010)$.

Eadie, et al. (2013) identified the drivers for implementing BIM within the UK construction contractors. They found that the greatest BIM's driver is the clash detection. Rodgers, et al. (2015) investigated the BIM's drivers within Australian small and medium-sized enterprises (SMEs). Harrison and Thurnell (2015) explored the advantages of BIM adoption towards consulting quantity surveying practice in New Zealand. Ghaffarianhoseini, et al. (2017) evaluated the associated advantages of BIM provided to the industry participants.

Based on the above researches, there is limited research studied about the BIM's drivers and benefits in quantity surveying profession in higher education institutions (HEIs). Besides, previous researches that explored the drivers and benefits of BIM incorporation into quantity surveying profession from the perspective of students are not very widespread. Hence, this study concentrated on analysing the drivers and benefits of BIM incorporation into quantity surveying profession. Since students will be the construction industry participants in future and there is a need for the construction industry participants to understand the drivers and benefits of BIM. Therefore the objectives of this study were to identify the perspective of students on drivers of BIM incorporation into quantity surveying profession and to identify the perspective of students on benefits of BIM incorporation into quantity surveying profession.

\section{LITERATURE REVIEW}

\section{Drivers of BIM Incorporation into Quantity Surveying Profession}

\section{Desire for Innovation to Remain Competitive}

BIM is an innovation technique to upgrade the building sector. Thus, it can increase output and value in construction industry. Quantity surveyors can adopt BIM as their innovation tools in the construction industry to ensure a better achievement in future. Besides, BIM can be adopted to become a part of construction project extranet (Eadie, et al., 2013). The driver to adopt this technology in construction companies was the desire to stand at the front of this aspect within the construction industry (Ruikar, Anumba and Carrillo, 2005; Eadie, et al., 2013).

\section{Improving the Capacity to Provide Whole Life Value to Client}

Actual worth for whole life can be offered via BIM adoption to convey cost, environmental, schedule, power and spatial evaluation to clients (Azhar, 2011). Building design can affect the construction and operation cost, increase working performance to offer a considerable savings of project to client and end-user (Deutsch, 2011). Besides, administration of facilities, destruction ways or to innovate the designs can be inspectedvia4D scenario modelling that allow them to be reused. BIM is useful in offering whole life value to client when it is used by qualified team to allow its function to be utilized entirely (Grilo and Jardim-Goncalves, 2010).

\section{Availability of Trained Staff (from Academia and Industry) Using BIM to teach the Students}

It is vital to involve trained staff who able to deal with each procedure during the adoption of BIM. Staff was considered as a part of BIM who acted as creators or collector of information from several origins and also acted as consumers of the processed information gained through building models (Arayici, et al., 2011; Ozorhon and Karahan, 2016). Besides, Ozorhon and Karahan (2016) claimed that while employing staff, upper management needs to ensure the staff was competent to do the job and foster their staff to comply with the latest procedures. It was due to the company required trained and qualified staff to adopt at the upper standards.

\section{BIM Software Availability and Affordability}

Omar, Nawi and Nursal (2014) defined where quantity surveyors offered with many types of BIM software. Hence, professionals are needed to pick suitable software for their building project before entering BIM project. The general norm to choose suitable BIM software were the availability and affordability of the software. Thus, some construction company will depend on the advertising programmes by software seller and the famous of the software to determine the choice of BIM software instead of identify the suitable requirements of their firms.

\section{Enabling Environment-Provision of IT Infrastructure}

IT is a beneficial infrastructure in this world. Current IT instrument offer many abilities such as improve interaction, communication and data sharing among professionals. Besides, the workplace quality of life (QOL) can be enhanced by adopting IT into the project which can solve the limitation demand across different level, department, and location which can offer an outstanding services to clients (Aziz, Nawawi and Ariff, 2016). 
Table 1. List of BIM drivers based on past studies

\begin{tabular}{|c|c|c|}
\hline $\mathbf{S} / \mathbf{n}$ & BIM Drivers & References \\
\hline D1 & $\begin{array}{l}\text { Desire for innovate to remain } \\
\text { competitive }\end{array}$ & $\begin{array}{l}\text { Ruikar, Anumba and Carrillo, 2005; Eadie, et al., 2013; } \\
\text { Ismail, Owen and Drogemuller, 2015; Babatunde, } \\
\text { et al., } 2018\end{array}$ \\
\hline D2 & $\begin{array}{l}\text { Improving the capacity to provide whole } \\
\text { life value to client }\end{array}$ & $\begin{array}{l}\text { Azhar, 2011; Deutsch, 2011; Eadie, et al., 2013; } \\
\text { Babatunde, et al., } 2018\end{array}$ \\
\hline D3 & $\begin{array}{l}\text { Availability of trained staff (from } \\
\text { academia and industry) using BIM to } \\
\text { teach the students }\end{array}$ & $\begin{array}{l}\text { Macdonald, 2012; Abubakar, et al., 2014; Badrinath, } \\
\text { Chang, Hsieh, 2016; Ozorhon and Karahan, 2016; } \\
\text { Babatunde, et al., } 2018\end{array}$ \\
\hline D4 & $\begin{array}{l}\text { BIM software availability and } \\
\text { affordability }\end{array}$ & $\begin{array}{l}\text { Macdonald, 2012; Eadie, et al., 2013; Abubakar, et al., } \\
\text { 2014; Babatunde, et al., } 2018\end{array}$ \\
\hline D5 & $\begin{array}{l}\text { Enabling environment-provision of IT } \\
\text { infrastructure }\end{array}$ & Oladapo, 2007; Babatunde, et al., 2018 \\
\hline D6 & $\begin{array}{l}\text { Cooperation and commitment of } \\
\text { professional bodies to its } \\
\text { implementation }\end{array}$ & $\begin{array}{l}\text { Eadie, et al., 2013; Rodgers, et al., 2015; Ozorhon and } \\
\quad \text { Cinar, 2015; Babatunde, et al., } 2018\end{array}$ \\
\hline D7 & Government support through legislation & $\begin{array}{l}\text { Arayici, et al., 2011; Eadie, et al., 2013; Ozorhon and } \\
\quad \text { Karahan, 2016; Babatunde, et al., } 2018\end{array}$ \\
\hline D8 & Awareness of BIM tangible benefits & Babatunde, et al., 2018 \\
\hline D9 & $\begin{array}{l}\text { Strong support from university } \\
\text { management and industry }\end{array}$ & $\begin{array}{l}\text { Badrinath, Chang and Hsieh, 2016; Babatunde, et al., } \\
2018\end{array}$ \\
\hline D10 & $\begin{array}{l}\text { Accreditation standards and } \\
\text { requirements to guide the } \\
\text { implementation of BIM within the } \\
\text { curriculum }\end{array}$ & Macdonald, 2012; Babatunde, et al., 2018 \\
\hline D11 & $\begin{array}{l}\text { Awareness of the IT among quantity } \\
\text { surveyors }\end{array}$ & Oladapo, 2007; Babatunde, et al., 2018 \\
\hline D12 & $\begin{array}{l}\text { Clients' demand for the use of BIM in } \\
\text { their project }\end{array}$ & $\begin{array}{l}\text { Eadie, et al., 2013; Ozorhon and Karahan, 2016; } \\
\text { Babatunde, et al., } 2018\end{array}$ \\
\hline
\end{tabular}

\section{Cooperation and Commitment of Professional Bodies to its Implementation}

The project issues able to be resolved via communication and cooperation among the design team and possession of a comprehensible BIM plan. Besides, quantity surveyor able to discuss with the design team regarding to their demand on BIM for quantity take off. Moreover, misinterpretation and dispute can be avoided while adopting BIM through coordination and cooperation between team members (Ozorhon and Cinar, 2015).

\section{Government Support through Legislation}

Eadie et al. (2013) identified that government will issues policy documentation to assure the successful adoption of electronic practices. Besides, Arayici et al. (2011) defined that government connected the BIM adoption into construction industry for value for money and sustainability of design and development. This policy reinforce stress on construction industry for BIM adoption within the public sector projects to be successful. The essential for professionals to entirely employ BIM into construction industry is due to the effect of UK government for the purpose of success before the time limit fix in its strategy documents.

\section{Awareness of BIM Tangible Benefits}

Kassem, Brogden and Dawood (2012) described that cost and time are the tangible benefits for the adoption of 4D planning. It is essential that advantages are acted as increasing the value to the project and construction company instead of only serving as a general advantages. Besides, 4D planning and BIM offered the attributes and profound advantages for project which caused the professionals difficult to explain quantitatively and hence reveal value in a tangible path.

\section{Strong Support from University Management and Industry}

Badrinath, Chang and Hsieh (2016) identified that to foster BIM enabled education in Construction Management department of Colorado State University, the university strive to exploit probing learning norm and results of initial studies. They also defined the need for the syllabus contain BIM education for students who pursuing quantity surveying in Malaysia. Besides, architectural, engineering, construction and operation (AECO) departmental curriculum syllabus needed to be improved with the involvement of AECO industry to support BIM, cooperative idea, research and development and education and advisory opportunities. 


\section{Accreditation Standards and Requirements to Guide the Implementation of BIM within the Curriculum}

Macdonald (2012) described that the need to create entirely fresh courses can be reducedvia the incorporation of the concept of cooperation and BIM techniques into current classes throughout the syllabus. The professional bodies must renew the certification requirements to reflect the industry need for BIM-qualified students and cooperative working to stimulate this curriculum revival. Accreditation standards offer the educational organization the biggest motivation to encourage modifications to their programs.

\section{Awareness of the IT among Quantity Surveyors}

Oladapo (2007) studied that all participants in the survey felt information technology (IT) brought significant influences to quantity surveyor and their services provision. The results shown that IT is have a strong effect on quantity surveyor's tasks such as the production of bill, final account, valuation, tendering and feasibility study.

\section{Clients' Demand for the Use of BIM in Their Project}

Ozorhon and Karahan (2016) identified clients' request was a vital driver to adopt BIM. Client needs is vitalin BIM tools selection and BIM development level. Distinct adoption level gain different reaction from client. Besides, client requirements are more vital when company adopt BIM at higher level. BIM adoption have to be more prudent at higher level. Next, outside forces from clients are a vital part for BIM adoption (Eadie, et al., 2013).

\section{Benefits of BIM Incorporation into Quantity Surveying Profession}

\section{BIM Provides Fast, Effective and Efficient Quantity Take-Off and Cost Estimation}

BIM can increase take-offs efficiency during estimation of budget phase (Stanley and Thurnell, 2014). 5D BIM can offer upper grade of cost detail that is beneficial at initial design phases and some software suppliers are currently enabling the comprehensive cost plans to be exploited via the model attach with the cost library for 5D (Thurairajah and Goucher, 2013). Besides, Chan, Olawumi and Ho (2019) described that BIM can automatically create certain information and quantities of materials which enhance the precision for estimating of cost and control in contrast of the taking off by hand.

\section{Produce Reliable and Accurate Quantities as well as Competitive Cost Estimates}

Thurairajah and Goucher (2013) studied that the participants of construction industry consented that the precision of cost estimates can be improved by automatic measurement. Automated quantification can improve the rate to update the estimates and boost the quantities precision when insufficient time to prepare an accurate measure. Besides, BIM can offer extra detail to assist in the enhancement of the reliability for cost estimating through the support for early supply chain engagement, early planning detail, faster forecast of the cost effect of design modifications and increase comprehension by enhanced visualization.

\section{It Updates Cost Plans with More Details as Design is Developed}

Wong, Salleh and Rahim (2014a) defined that during the developed design phase, there are more comprehensive data become accessible, the design will be gradually evolved. The cost database in BIM contains several entries that permit for the automatic and better thorough production of basic cost plans via integrated automation service from the model estimates (Cheung, et al., 2012; Thurairajah and Goucher, 2013).

\section{It Generates Accurate Cost Estimates for Various Design Alternatives}

Wong, Salleh and Rahim (2014b) further investigated that clients demand for alternatives design approaches to assess and contrast for determination of the most suitable design and prevent expensive construction techniques. Hence, BIM allowed the quantity surveyors to produced precise cost estimates for different options of design.

\section{Time Savings in the Preparation of Estimating Costs}

Lock (2007) studied that the project successfulness affected by project time taken. Through 5D BIM programme, project cost can be adjusted quickly as design changes can be examined via online by the project team. Next, BIM adoption can reduce the duration to create cost estimates.

\section{Reduction of Requests for Information}

Smith (2014) analysed that BIM able to improve the capability to solve requests for information in actual time. Besides, Ghaffarianhoseini, et al. (2017) investigated clash detection able to minimise the amount of request for information. This is considered as one of the benefit which is significant importance for BIM. Little requests for information represents lesser change orders which ensure a higher precise cost management and savings in cost.

\section{Clash Detection to Reduce Design Errors}

Moreover, Thurairajah and Goucher (2013) identified that one of the primary benefit of BIM to cost consultants is that the probability to detect clashes among several designs created. This can be accomplished by converting the designs of architecture, structure and mechanical, electrical and plumbing (MEP) into software competent with clash detection. Besides, this able to reduce the errors in design and decrease the matters on site. 


\section{Simplify Cost Checking and Update}

Wong, Salleh and Rahim (2014a; 2014b) claimed that cost checking against cost plan is a primary role for BIM during technical design stage. In order to guarantee that the cost estimates included all design items, it is significant to involve a cost checking and monitoring. Hence, screen visual inspection from BIM model can secure that all elements are measured. Thus, BIM offered benefit that cost checking can be conducted rapidly to ensure all elements are measured.

\section{Improved Visualization for Better Understanding of Designs for Measurement and Minimise Omissions}

Stanley and Thurnell (2014) defined visualization was an advantageous for quantity surveyor. It allowed quantity surveyors to observe from BIM model which help them to further clear about the drawings to prepare taking off and ensure every items are measured. Besides, less assumption will be needed as BIM allowed quantity surveyors to observe the different directions of the building in 3D model (Samphaongoen, 2010; Hasan and Rasheed, 2019).

Table 2. List of BIM benefits based on past studies

\begin{tabular}{|c|c|c|}
\hline $\mathbf{S} / \mathbf{n}$ & BIM Benefits & References \\
\hline B1 & $\begin{array}{l}\text { BIM provides fast, effective and } \\
\text { efficient quantity take-off and cost } \\
\text { estimation }\end{array}$ & $\begin{array}{l}\text { Zhou, et al., 2012; Stanley and Thurnell, 2014; } \\
\text { Babatunde, et al., 2018; Chan, Olawumi and Ho, } \\
\text { 2019; Hasan and Rasheed, } 2019\end{array}$ \\
\hline B2 & $\begin{array}{l}\text { Produce reliable and accurate quantities } \\
\text { as well as competitive cost estimates }\end{array}$ & $\begin{array}{l}\text { Azhar, 2011; Deutsch, 2011; Thurairajah and Goucher, } \\
\text { 2013; Babatunde, et al., } 2018\end{array}$ \\
\hline B3 & $\begin{array}{l}\text { It updates cost plans with more details as } \\
\text { design is developed }\end{array}$ & $\begin{array}{l}\text { Wong, Salleh and Rahim, 2014a; Wong, Salleh and } \\
\text { Rahim, 2014b; Babatunde, et al., } 2018\end{array}$ \\
\hline B4 & $\begin{array}{l}\text { It generates accurate cost estimates for } \\
\text { various design alternatives }\end{array}$ & $\begin{array}{l}\text { Wong, Salleh and Rahim, 2014a; Wong, Salleh and } \\
\text { Rahim, 2014b; Babatunde, et al., } 2018\end{array}$ \\
\hline B5 & $\begin{array}{l}\text { Time savings in the preparation of } \\
\text { estimating costs }\end{array}$ & Eadie, et al., 2013; Babatunde, et al., 2018 \\
\hline B6 & Reduction of requests for information & $\begin{array}{l}\text { Ghaffarianhoseini, et al., 2017; Babatunde, et al., 2018; } \\
\text { Hasan and Rasheed, } 2019\end{array}$ \\
\hline B7 & Clash detection to reduce design errors & $\begin{array}{l}\text { Thurairajah and Goucher, 2013; Eadie, et al., 2013; } \\
\text { Wong, Salleh and Rahim, 2014a; Wong, Salleh and } \\
\text { Rahim, 2014b; Babatunde, et al., 2018; Hasan and } \\
\text { Rasheed, } 2019\end{array}$ \\
\hline B8 & Simplify cost checking and update & $\begin{array}{l}\text { Wong, Salleh and Rahim, 2014a; Wong, Salleh and } \\
\text { Rahim, 2014b; Babatunde, et al., } 2018\end{array}$ \\
\hline B9 & $\begin{array}{l}\text { Improved visualization for better } \\
\text { understanding of designs for } \\
\text { measurement and minimize } \\
\text { omissions }\end{array}$ & $\begin{array}{l}\text { Sylvester and Dietrich, 2010; Zhou, et al., 2012; } \\
\text { Harrison and Thurnell, 2015; Babatunde, et al., } \\
\text { 2018; Hasan and Rasheed, } 2019\end{array}$ \\
\hline B10 & $\begin{array}{l}\text { Automatic quantification of BOQs } \\
\text { preparation }\end{array}$ & $\begin{array}{l}\text { Zhou, et al., 2012; Wong, Salleh and Rahim, 2014a; } \\
\text { Wong, Salleh and Rahim, 2014b; Babatunde, et al., } \\
2018\end{array}$ \\
\hline B11 & $\begin{array}{l}\text { Data storage in central coordinated } \\
\text { model }\end{array}$ & $\begin{array}{l}\text { Wong, Salleh and Rahim, 2014a; Wong, Salleh and } \\
\text { Rahim, 2014b; Babatunde, et al., } 2018\end{array}$ \\
\hline B12 & $\begin{array}{l}\text { Enhance communication and } \\
\text { collaboration amongst team } \\
\text { members }\end{array}$ & $\begin{array}{l}\text { Zhou, et al., 2012; Smith, 2014; Stanley and Thurnell, } \\
\text { 2014; Babatunde, et al., 2018; Georgiadou, 2019; } \\
\text { Hasan and Rasheed, } 2019\end{array}$ \\
\hline B13 & $\begin{array}{l}\text { Improve cost database management } \\
\text { which reduces loss of information }\end{array}$ & $\begin{array}{l}\text { Arayici, Egbu and Coates, 2012; Wong, Salleh and } \\
\quad \text { Rahim, 2014a; Babatunde, et al., } 2018\end{array}$ \\
\hline B14 & Rapid identification of design changes & $\begin{array}{l}\text { Azhar, 2011; Wong, Salleh and Rahim, 2014a; Wong, } \\
\text { Salleh and Rahim, 2014b; Babatunde, et al., } 2018\end{array}$ \\
\hline
\end{tabular}

\section{Automatic Quantification of BOQs Preparation}

Wong, Salleh and Rahim (2014a; 2014b) identified that bill of quantities (BOQs) production was an important service by a quantity surveyors to perform at technical design phase. When preparing BOQs, quantification will be a time consuming job. Hence, automatic quantification of BOQs preparation through BIM allow take offs and measurements to be produced through the model for cost estimate which improve the working performance of quantity surveyors because it can reduce time consumption and mistakes which exist in the conventional method.

\section{Data Storage in Central Coordinated Model}

Wong, Salleh and Rahim (2014a; 2014b) identified that designer's drawings, information and specifications are vital for quantity surveyor to conduct comprehensive cost estimation at developed design phase. Thus, BIM able to correct 
such unproductivity through processing a large amount of distinct data from a sole database. BIM's intelligent information administration through an information database repository within the model foster data sharing and gaining as compared with conventional methods (Cheung, et al. 2012; Thurairajah and Goucher, 2013).

\section{Enhance Communication and Collaboration amongst Team Members}

Arayici, et al. (2011) claimed that the performance of the development project can be enhanced by collaboration among the project participants. Besides, BIM biggest input was the capacity for modernizing models in actual time, remove conflicts, examine alterations during initiate design phase and interchange precious project data in the project lifespan. This allow effective dispute settlement within project team and enhance collaboration among the project participants (Georgiadou, 2019).

\section{Improve Cost Database Management which Reduces Loss of Information}

Arayici, Egbu and Coates (2012) identified that a thorough BIM model and an overall and updated cost database is needed to reach the greatest efficiencies. Connections are recorded automatically among the types of the object and cost database for both present and future purposes. Thus, management of cost database is important to reduce the loss of information because loss of information may result in the adoption of an incorrect information in the project.

\section{Rapid Identification of Design Changes}

Wong, Salleh and Rahim (2014a; 2014b) claimed that through the adoption of BIM, any alteration in the drawings can be shown automatically through the model. Besides, it also being spread over each view in drawing. Thus, the newest design alteration will be automatically obtained to represent present revisions of the design drawing.

\section{METHODOLOGY}

The data in this study was gathered through online questionnaire. Slattery, et al. (2011) described questionnaires as a particular tool or instrument for collecting quantitative basic data for a research. Besides, it also knowns as scales when a quantified score is generated by their evaluation. Moreover, it is formed by a number of questions and are generally self-managed. The questions involved particular interest ideas or elements which are considered worth investigating and able to be circulated through several methods such as online, e-mail or read to respondents. Furthermore, Roodpa and Rani (2017) identified that by using questionnaire, there will be a standardized manner in gathering of quantitative data and hence the data that used for evaluation are internally persistent and coherent. Subsequently, it should involve a specific aim which connected with the research objectives and it is necessary to clarify from the outset how outcomes will be adopted. There are several advantages in adopting questionnaire survey which included it enables a broad range of participants and thus resulting in a large-scaled of outcomes. Besides, as compared with other surveys such as interview, the cost necessary for this method is relatively lower and higher convenience. Moreover, by using questionnaire surveys, the participants are most probably not affected by other people's views and hence it will reduce the prejudice reaction (Szolnoki and Hoffmann, 2013).Online questionnaire was a more suitable way for this research because this study involved a large scale of participants targeted from undergraduate students who are studying Bachelor of Science (Hons) Quantity Surveying in UTAR. The completed questionnaire was circulated to the respondents to allow the respondents to respond. There was a necessary where the participants were required to answer the questionnaire within the stipulated duration. It was essential for the respondents to respond the questionnaire via online and once the questionnaire was accomplished, there is a necessary for the respondents to submit the responses to the researcher. The reason for targeting undergraduate students is due to their recognition of the learning outcomes of the quantity surveying programmes (Perera, et al., 2013). On top of that, all the data collected were coded into computer and evaluated through Statistical Package for the Social Sciences (SPSS).

\section{FINDINGS AND DISCUSSION}

Background of Respondents

Years of Study

Table 3. The frequency and percentage of years of study of respondents

\begin{tabular}{cccccc}
\hline & Year of & Frequency & Percent & Valid Percent & $\begin{array}{c}\text { Cumulative } \\
\text { Percent }\end{array}$ \\
\hline Study & Year 1 & 47 & 22.5 & 22.5 & 22.5 \\
& Year 2 & 49 & 23.4 & 23.4 & 45.9 \\
& Year 3 & 66 & 31.6 & 31.6 & 77.5 \\
& Year 4 & 47 & 22.5 & 22.5 & 100.0 \\
\hline
\end{tabular}


Table 3 shows the category of year of study of respondents. The results indicated that there have 47 students from Year 1, 49 students from Year 2, 66 students from Year 3 and 47 students from Year 4 with a percentage of $22.5 \%, 23.4$ $\%, 31.6 \%$ and $22.5 \%$ respectively. Table 3 shows that Year 3 students occupied the highest percentage.

\section{Experience in Using BIM}

Table 4. The frequency and percentage of years of study of respondents

\begin{tabular}{cccccc}
\hline & $\begin{array}{c}\text { Experience in } \\
\text { Using BIM }\end{array}$ & Frequency & Percent & $\begin{array}{c}\text { Valid } \\
\text { Percent }\end{array}$ & $\begin{array}{c}\text { Cumulative } \\
\text { Percent }\end{array}$ \\
\hline Valid & Yes & 112 & 53.6 & 53.6 & 53.6 \\
& No & 97 & 46.4 & 46.4 & 100.0 \\
& Total & 209 & 100.0 & 100.0 & \\
\hline
\end{tabular}

Moreover, Table 4 presented the category of respondents' experience in using BIM. The results shown that there have 112 respondents with $53.6 \%$ of respondents experienced in using BIM and 97 respondents with $46.4 \%$ of respondents were inexperienced in using BIM. Table 4 shows that respondents with experienced in using BIM took higher percentage.

Table 5. The frequency and percentage of gender of respondents

\begin{tabular}{cccccc}
\hline & Gender & Frequency & Percent & Valid Percent & $\begin{array}{c}\text { Cumulative } \\
\text { Percent }\end{array}$ \\
\hline Valid & Male & 98 & 46.9 & 46.9 & 46.9 \\
& Female & 111 & 53.1 & 53.1 & 100.0 \\
& Total & 209 & 100.0 & 100.0 & \\
\hline
\end{tabular}

Furthermore, Table 5 shows the category of gender of the respondents. The results presented that there are $46.9 \%$ of the respondents which equivalent to 98 respondents are male and the remaining $53.1 \%$ of the respondents which equivalent to 111 respondents are female. From table above, female respondents occupied a larger percentage than male respondents.

\section{Mean Ranking for the Perspective of Students on Drivers of BIM Incorporation into Quantity Surveying Profession}

Table 6 shows that most of the respondents think that D02 with a mean of 4.11 was the most affective driver to incorporate BIM into quantity surveying profession. It is due to BIM can offer energy, schedule, environmental, cost and spatial analysis that allow project team to work cooperatively to offer an actual whole life value for their clients.

On the other hand, D01 won the second place with a mean of 4.09. Since the current construction market in Malaysia is getting more and more competitive, companies are forced to improve their capabilities in innovation to obtain the competitive advantage in the construction industry.

Subsequently, D09 ranked as the third vital driver with a mean of 4.01. This is because university is a place where quantity surveying's students can learn basic knowledge about BIM. Therefore, support from university management and industry can help students who studying quantity surveying to learn more about BIM and understand how BIM is applied in project.

Table 6. Mean ranking for the perspective of students on drivers of BIM incorporation into quantity surveying profession

\begin{tabular}{ccccc}
\hline & N & Mean & Std. Deviation & Mean Ranking \\
\hline D02 & 209 & 4.11 & .667 & 1 \\
D01 & 209 & 4.09 & .725 & 2 \\
D09 & 209 & 4.01 & .791 & 3 \\
D06 & 209 & 3.93 & .697 & 4 \\
D03 & 209 & 3.93 & .782 & 5 \\
D10 & 209 & 3.90 & .724 & 6 \\
D08 & 209 & 3.87 & .739 & 7 \\
D11 & 209 & 3.85 & .737 & 8 \\
D05 & 209 & 3.81 & .695 & 10 \\
D07 & 209 & 3.80 & .817 & 11 \\
D12 & 209 & 3.79 & .787 & 12 \\
D04 & 209 & 3.77 & .817 & \\
Valid N & 209 & & & \\
(listwise) & & & & \\
\hline
\end{tabular}


Table 7. Mean ranking for the perspective of students on drivers of BIM incorporation into quantity surveying profession

\begin{tabular}{ccccc}
\hline & N & Mean & Std. Deviation & Mean Ranking \\
\hline B01 & 209 & 4.23 & .699 & 1 \\
B05 & 209 & 4.20 & .732 & 2 \\
B09 & 209 & 4.15 & .724 & 3 \\
B03 & 209 & 4.09 & .722 & 4 \\
B02 & 209 & 4.06 & .725 & 5 \\
B04 & 209 & 4.06 & .732 & 6 \\
B08 & 209 & 4.02 & .737 & 7 \\
B07 & 209 & 4.01 & .710 & 8 \\
B14 & 209 & 4.00 & .714 & 9 \\
B13 & 209 & 4.00 & .756 & 10 \\
B10 & 209 & 3.98 & .759 & 12 \\
B11 & 209 & 3.94 & .741 & 13 \\
B12 & 209 & 3.94 & .770 & 14 \\
B06 & 209 & 3.73 & .764 & \\
Valid N (listwise) & 209 & & & 11 \\
\hline
\end{tabular}

Table above indicated B01 won the first place with a mean of 4.23. It is because BIM can offer a precise quantity take-off and converts it into accurate scheduling and estimating of cost within a short time. This benefit will help the company to increase their productivity and performance.

Furthermore, B05 was the second place with a mean of 4.20. Time taken of a project is critical to allow the project can be completed successfully. Besides, sometimes there is a design changes occurred in a construction project, hence through the use of BIM, the cost estimates can be adjusted quickly because the project team can examine the changes in design through online.

On top of that, B09 ranked as the third vital benefit with a mean of 4.15 because BIM can produce 3D model of building that allow quantity surveyor to observe and understand the design of the building from different direction, hence omissions and assumption can be reduced when preparing measurement.

Factor Analysis for the Perspective of Students on Drivers of BIM Incorporation into Quantity Surveying Profession

Table 8. KMO and Bartlett's test for drivers of BIM incorporation

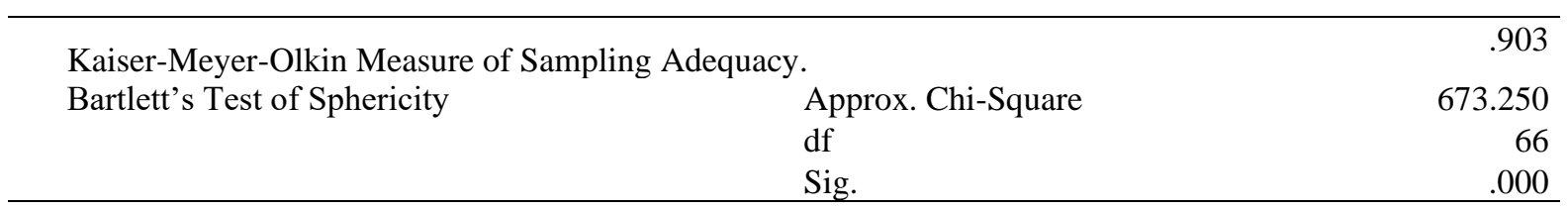

The value of KMO in this research is 0.903 which is above 0.6 and this presented that it can be continued to be carried out for this study. Meanwhile, Bartlett's Test of Sphericity is applied for testing the hypothesis that the correlation matrix is an identity matrix and the result presented 0.000 which is smaller than 0.05 . 
Table 9. Rotated component matrix for drivers of BIM incorporation

\begin{tabular}{llll}
\hline & \multicolumn{3}{c}{ Component } \\
\cline { 3 - 4 } D12 & 1 & 2 \\
D09 & .777 & \\
D08 & .680 & \\
D07 & .658 & \\
D06 & .615 & .463 \\
D11 & .609 & \\
D10 & .603 & .761 \\
D04 & .542 & .747 \\
D05 & .527 & .497 \\
D01 & & .473 \\
D03 & & \\
D02 & .423 & \\
\hline
\end{tabular}

Extraction Method: Principal Component Analysis.

Rotation Method: Varimax with Kaiser Normalization.

a. Rotation converged in 3 iterations.

Table 9 presented the rotated component matrix which extracted the 12 drivers into two components. The table above presented that the items loading of the variables with items loading exceeding 0.3 in component 1 and 2. Component 1 represented the external influences and component 2 represented capabilities of company.

Component 1 named as external influences because these drivers are related to the influences from external to integrate BIM into quantity surveying profession. From table 9, D12 is the highest value with a value of 0.777 may be due to the success of a project is rely on the client's satisfaction. It is due to client is the project owner and they are the one who pay for the project. Next, D09 has a value of 0.680. This is an external influence because this is an external support where a quantity surveying firm gained. When student obtained the knowledge of BIM from university, it will help the quantity surveying firm to adopt BIM more easily.

Component 2 named as capabilities of company because all drivers are related to the capabilities of a company to incorporate BIM into quantity surveying profession successfully. In component 2, D05 is the highest value with value of 0.761. IT is a technology that can improve economics of country. The used of IT in a project help project team to solve limitations such as communication across distinct department and location. Next, D01also grouped in component 2 with value of 0.747 because BIM is an innovation technique that can improve building sector and help the company to increase output and value in construction industry.

Factor Analysis for the Perspective of Students on Benefits of BIM Incorporation into Quantity Surveying Profession

Table 10. KMO and Bartlett's test for benefits of BIM incorporation

\begin{tabular}{|c|c|c|}
\hline \multicolumn{3}{|c|}{ Kaiser-Meyer-Olkin Measure of Sampling Adequacy. } \\
\hline Bartlett's Test of Sphericity & $\begin{array}{l}\text { Approx. Chi-Square } \\
\text { df }\end{array}$ & $\begin{array}{r}1261.323 \\
91\end{array}$ \\
\hline & Sig. & .000 \\
\hline
\end{tabular}

Factor analysis for benefits of BIM was subsequently carried out. From Table 10, the value of KMO is 0.936 which is higher than 0.6 and it represented that it can be continued to be carried out for this study. Besides, Bartlett's Test of Sphericity is applied for testing the hypothesis that the correlation matrix is an identity matrix and the result presented 0.000 which is smaller than 0.05 . 
Table 11. Rotated component matrix for benefits of BIM incorporation

\begin{tabular}{llll}
\hline & & Component & \\
\cline { 2 - 3 } & & 1 & 2 \\
B02 & .798 & \\
B01 & .765 & \\
B04 & .714 & \\
B03 & .673 & .479 \\
B05 & .620 & .474 \\
B14 & .590 & .476 \\
B10 & .561 & .464 \\
B08 & .546 & .772 \\
B09 & .527 & .678 \\
B06 & & .582 \\
B12 & & .570 \\
B13 & .410 & .530 \\
B07 & .431 & .501 & \\
B11 & & \\
\hline
\end{tabular}

Extraction Method: Principal Component Analysis.

Rotation Method: Varimax with Kaiser Normalization.

a. Rotation converged in 3 iterations.

Table 11 shows rotated component matrix which extracted 14 benefits into two components. Table above presented the items loading of the variables with items loading exceeding 0.3 in component 1 and 2. Component 1 represented productivity aspect and component 2 represented information platform.

Component 1 named as productivity aspect because all benefits included in component 1 are related to the improvement in the productivity of project through incorporation of BIM into quantity surveying profession. From table above, B02 is the greatest value in component 1 with a value of 0.798 because when quantity of elements is measured accurately, project can be completed smoothly and enhance productivity of quantity surveyor. Besides, a precise quantities for the project can produce a competitive cost estimates for the project. Moreover, B01 also grouped in component 1 with a value of 0.765 because this benefit can enhance the productivity of quantity surveyor. It is due to BIM can automatic produce the quantity needed for the project via BIM model and help to reduce the omission and mistake in the project. Besides, BIM adoption can also produce an automation of cost estimation.

Apart from that, component 2 is named as information platform because the benefits included in component 2 are related to the information of the project. In component 2, the highest value is B06 with a value of 0.772 may due to all the information which related to the project will be gathered in BIM model. Besides, since BIM having the function where clash in design can be detected, hence the need to request for information will be reduced. Next, B12 also grouped in component 2 with a value of 0.678 because information can be share among the project team members via communication and collaboration between each other.

\section{CONCLUSION}

In conclusion, two objectives have been formulated and needed to be achieved in this research which were to identify the perspective of students on drivers of BIM incorporation into quantity surveying profession and to identify the perspective of students on benefits of BIM incorporation into quantity surveying profession.

In this study, all the drivers are categorized into two components. Component 1 named as external influences and component 2 named as capabilities of company. Besides, through the mean ranking of drivers in this study, the main drivers was enhancing the capacity for providing client with a whole life value while the least influence driver was BIM software availability and affordability. Moreover, all the benefits were also categorized into two components. Component 1 named as productivity aspect while component 2 named as information platform. Next, through the mean ranking of benefits in this research, the main benefits was BIM offers quick, effective and efficient quantity take-off as well as estimation of cost while the least influence benefits was reduction of requests for information.

Moreover, this research offered significant contributions to the undergraduate students who are studying Bachelor of Science (Hons) Quantity Surveying, university that offered with the course of Quantity Surveying and quantity surveyors who are employed in construction firms. Next, study limitation were the respondents in this study were focused on undergraduate students in UTAR, time constraints, quantitative research used in this research and limited drivers and benefits included in this study. Besides, recommendations discussed in this study were the consideration of respondents to be focused on industry person to increase the reliability of the outcomes, increase time frame to collect data, involve qualitative research method in this study and increase drivers and benefits consisted in this study. 


\section{REFERENCES}

Abubakar, M., Ibrahim, M., Kado, D. \& Bala, K. (2014). Contractors Perception of the Factors Affecting Building Information Modelling (BIM) Adoption in the Nigerian Construction Industry. Computing in Civil and Building Engineering, 167-178.

Arayici, Y., Coates, S., Koskela, L.J., Kagioglou, M., Usher, C. \& O’Reilly, K. (2011). BIM Adoption and Implementation for Architectural Practices. Structural Survey, 29(1), 7-25.

Arayici, Y., Egbu, C. \& Coates, P. (2012). Building Information Modelling (BIM) Implementation and Remote Construction Projects: Issues, Challenges and Critiques. Journal of Information Technology in Construction, 17, 75-92.

Azhar, S. (2011). Building Information Modelling (BIM): Trends, Benefits, Risks and Challenges for the AEC Industry. Leadership and Management in Engineering, 11(3), 241-252.

Aziz, N. D., Nawawi, A. H. \& Ariff, N. R. M. (2016). ICT Evolution in Facilities Management (FM): Building Information Modelling (BIM) as the Latest Technology. Procedia - Social and Behavioral Sciences, 234, 363-371.

Babatunde, S. O., Ekundayo, D., Babalola, O. \& Jimoh, J. A. (2018). Analysis of the Drivers and Benefits of BIM Incorporation into Quantity Surveying Profession. Journal of Engineering, Design and Technology, 16(5), 750-766.

Badrinath, A. C., Chang, Y. T. \& Hsieh, S. H. (2016). A Review of Tertiary BIM Education for Advanced Engineering Communication with Visualization. Visualization in Engineering, 4(1), 9-17.

Chan, D. W. M., Olawumi, T. O. \& Ho, A. M. L. (2019). Perceived Benefits of and Barriers to Building Information Modelling (BIM) Implementation in Construction: The Case of Hong Kong. Journal of Building Engineering, 25.

Cheung, F. K. T., Rihan, J., Tah, J. H. M., Duce, D. \& Kurul, E. (2012). Early Stage Multi-Level Cost Estimation for Schematic BIM Models. Automation in Construction, 27, 67-77.

Deutsch, R. (2011). BIM and Integrated Design. New Jersey: John Wiley \& Sons.

Eadie, R., Odeyinka, H., Browne, M., McKeown, C. \& Yohanis, M. (2013). An Analysis of the Drivers for Adopting Building Information Modelling. Journal of Information Technology in Construction, 18, 338-352.

Georgiadou, M. C. (2019). An Overview of Benefits and Challenges of Building Information Modelling (BIM) Adoption in UK Residential Projects. Construction Innovation, 19(3), 298-320.

Ghaffarianhoseini, A., Tookey, J., Ghaffarianhoseini, A., Naismith, N., Azhar, S., Efimova, O. \& Raahemifar, K. (2017). Building Information Modelling (BIM) Uptake: Clear Benefits, Understanding Its Implementation, Risks and Challenges. Renewable and Sustainable Energy Reviews, 75, 1046-1053.

Goucher, D. \& Thurairajah, N. (2012). Usability and Impact of BIM on Early Estimation Practices: Cost Consultant's Perspective. Management of Construction: Research to Practice, 2, 555-569.

Grilo, A. \& Jardim-Goncalves, R. (2010). Value Proposition on Interoperability of BIM and Collaborative Working Environments. Automation in Construction, 19(5), 522-530.

Hasan, A.N. and Rasheed, S.M. (2019). The Benefits of and Challenges to Implement 5D BIM in Construction Industry. Civil Engineering Journal, 5(2), 412-421.

Harrison, C. \& Thurnell, D. (2015). BIM Implementation in a New Zealand Consulting Quantity Surveying Practice. International Journal of Construction Supply Chain Management, 5(1), 1-15.

Isikdag, U. \& Underwood, J. (2010). A Synopsis of the Handbook of Research in Building Information Modelling. In: CIB World Building Congress W78 Track. Salford Quays, 10-13 May 2010. The Lowry: IGI Global.

Ismail, N. A. A., Owen, R. \& Drogemuller, R. (2015). Cost Estimating Practice Incorporating Building Information Modelling (BIM): Malaysian Quantity Surveyors Perspectives. In: The $7^{\text {th }}$ International Conference of SuDBE2015. UK, 27-29 July 2015. Reading.

Kassem, M., Brogden, T. \& Dawood, N. (2012). BIM and 4D Planning: a Holistic Study of the Barriers and Drivers to Widespread Adoption. Journal of Construction Engineering and Project Management, 2(4).

Lock, D. (2007). Project Management. ${ }^{\text {th }}$ ed. Aldershot: Gower Publishing Limited.

Macdonald, J.A. (2012). A Framework for Collaborative BIM Education Across the AEC Discipline. In: $37^{\text {th }}$ Annual Conference of the Australasian Universities Building Educators Association (AUBEA). Australia, 4-6 July 2012. Sydney: The University of New South Wales.

Oladapo, A. A. (2007). An Investigation into the Use of ICT in the Nigerian Construction Industry. Journal of Information Technology in Construction (ITcon), 24(1), 261-277.

Olatunji, O. A., Sher, W. \& Gu, N. (2010). Building Information Modelling and Quantity Surveying Practice. Emirates Journals for Engineering Research, 15(1), 67-70.

Olawumi, T. O. \& Chan, D. W. M. (2018). Identifying and Prioritizing the Benefits of Integrating BIM and Sustainability Practices in Construction Projects: A Delphi survey of International Experts. Sustainable Cities and Society, 40, 16-27.

Omar, M. F., Nawi, M. N. M. \& Nursal, A. T. (2014). Towards the Significance of Decision Aid in Building Information Modelling (BIM) Software Selection Process. In: E3S Web of Conferences. Malaysia, 14 September 2014. Kedah: EDP Sciences.

Ozorhon, B. \& Cinar, E. (2015). Critical Success Factors of Enterprise Resource Planning Implementation in Construction: Case of Turkey. Journal of Management in Engineering, 31(6).

Ozorhon, B. \& Karahan, U. (2016). Critical Success Factors of Building Information Modelling Implementation. Journal of Management in Engineering, 33(3).

Perera, S., Pearson, J., Ekundayo, D. \& Zhou, L. (2013). Professional, Academic and Industrial Development Needs: A Competency Mapping and Expert Opinion Review. International Journal of Strategic Property Management, 17(2), 143-160.

Rodgers, C., Hosseini, M. R., Chileshe, N. \& Rameezdeen, R. (2015). Building Information Modelling (BIM) within the Australian Construction Related Small and Medium Sized Enterprises: Awareness, Practices and Drivers. In: Association of Researchers in Construction Management, ARCOM 2015: Proceedings of the $31^{\text {st }}$ Annual Conference of the Association of Researchers in Construction Management. England, 7-9 September 2015. Lincoln, England: ARCOM.

Roodpa, S. \& Rani, M. S. (2017). Questionnaire Designing for a Survey. The Journal of Indian Orthodontic Society, 46(4), $273-277$.

Ruikar, K., Anumba, C. J. \& Carrillo, P. M. (2005). End-User Perspectives on Use of Project Extranets in Construction Organisations. Engineering, Construction and Architectural Management, 12(3), 222-235.

Samphaongoen, P. (2010). A Visual Approach to Construction Cost Estimating. Master. Marquette University.

Slattery, E. L., Voelker, C. C. J., Nussenbaum, B., Rich, J. T., Paniello, R. C. \& Neely, J. G. (2011). A Practical Guide to Surveys and 
Questionnaires. Otolaryngology - Head and Neck Surgery, 144(6), 831-837.

Smith, P. (2014). BIM and the 5D Project Cost Manager. Procedia - Social and Behavioral Sciences, 119, 475-484.

Stanley, R. \& Thurnell, D. (2014). The Benefits of, and Barriers to, Implementation of 5D BIM for Quantity Surveying in New Zealand. Australasian Journal of Construction Economics and Building, 14(1), 105-117.

Sylvester, K. E. \& Dietrich, C. (2010). Evaluation of Building Information Modelling (BIM) Estimating Methods in Construction Education. In: 46 ${ }^{\text {th }}$ ASC Annual International Conference Proceedings Associated Schools of Construction Boston. North Carolina. Greenville.

Szolnoki, G. \& Hoffmann, D. (2013). Online, Face-To-Face and Telephone Surveys - Comparing Different Sampling Methods in Wine Consumer Research. Wine Economics and Policy, 2(2), 57-66.

Thurairajah, N. \& Goucher, D. (2013). Advantages and challenges of using BIM: A Cost Consultant's Perspective. In: Associated Schools of Construction, $49^{\text {th }}$ ASC Annual International Conference Proceedings. California, April 2013. San Luis Obispo.

Wong, P. F., Salleh, H. \& Rahim, F. A. (2014a). Capability of Building Information Modelling Application in Quantity Surveying Practice. Journal of Surveying, Construction and Property (JSCP), 5(1), 1-13.

Wong, P. F., Salleh, H. \& Rahim, F. A. (2014b). The Relationship of Building Information Modelling (BIM) Capability in Quantity Surveying Practice and Project Performance. International Journal of Civil and Environmental Engineering, 8(10), 1039-1044.

Wong, K. A., Wong, K. F. \& Nadeem, A. (2011). Building Information Modelling for Tertiary Construction Education in Hong Kong. Journal of Information Technology in Construction, 16, 467-476.

Zhou, L., Perera, S., Udeaja, C. \& Paul, C. (2012). SME Readiness of BIM: A Case Study of a Quantity Surveying Organisation. In: First UK Academic Conference on BIM. UK, 5-7 September 2012. Newcastle upon Tyne: Northumbria University.

\section{ACKNOWLEDGEMENT}

This research was supported by Universiti Tunku Abdul Rahman, Sungai Long Campus, Malaysia. The authors would like to thank Assistant Professor Dr Felicia Yong Yan Yan for her suggestions on preparing the manuscript.

\section{DECLARATION OF CONFLICT OF INTEREST}

The authors declare that there is no conflict of interest regarding the publication of this paper.

\section{AUTHORS' BIOGRAPHY}

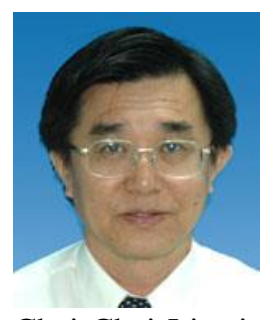

Chai-Chai Lim is an Assistant Professor in Lee Kong Chian Faculty of Engineering and Science at Universiti Tunku Abdul Rahman, Sungai Long Campus, Malaysia. He received his MSc (Construction Management) from Heriot-Watt University and Dip in Technology (Building) from Kolej Tunku Abdul Rahman.

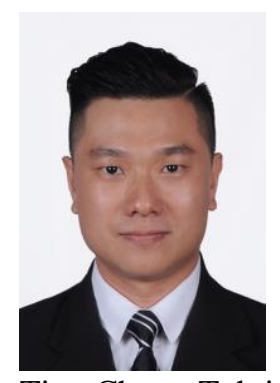

Tien-Choon Toh is an Assistant Professor in Lee Kong Chian Faculty of Engineering and Science at Universiti Tunku Abdul Rahman, Sungai Long Campus, Malaysia. He received his PhD (Quantity Surveying), MSc (Construction Management), BSc (Hons) (Construction), and Dip in Quantity Surveying from Universiti Teknologi Malaysia. 


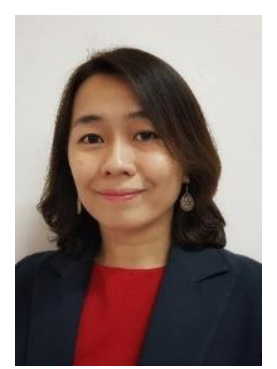

Yoke-Lian Lew is an Assistant Professor in Lee Kong Chian Faculty of Engineering and Science at Universiti Tunku Abdul Rahman, Sungai Long Campus, Malaysia. She received her PhD (Project Management), MSc (Project Management) and BEng (Hons) (Civil) from Universiti Putra Malaysia, and Dip in Civil Engineering from Politeknik Ungku Omar.

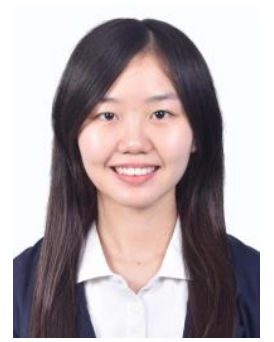

Chin-Xian Lau is a Former Undergraduate Student in Lee Kong Chian Faculty of Engineering and Science at Universiti Tunku Abdul Rahman, Sungai Long Campus, Malaysia. She received her BSc (Hons) (Quantity Surveying) from Universiti Tunku Abdul Rahman.

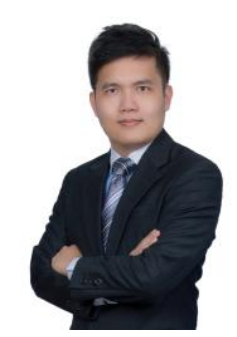

Kai-Chen Goh is an Associate Professor in Faculty of Technology Management and Business at Universiti Tun Hussein Onn Malaysia, Malaysia. He received his PhD (Built Environment and Engineering) from Queensland University of Technology, and MSc (Construction Management), BSc (Hons) (Construction) and Dip in Quantity Surveying from Universiti Teknologi Malaysia.

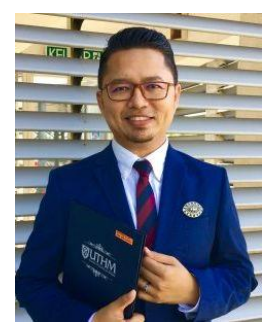

Md Asrul Nasid Masrom is an Associate Professor in Faculty of Technology Management and Business at Universiti Tun Hussein Onn Malaysia, Malaysia. He received his PhD (Construction Management) from Queensland University of Technology, and MSc (Construction Contract Management), BSc (Hons) (Building) and Dip in Quantity Surveying from Universiti Teknologi Malaysia.

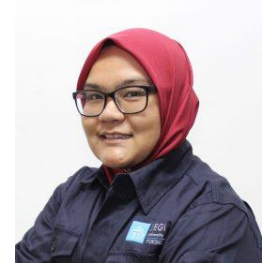

Nadzirah Zainordin is a Senior Lecturer in Faculty of Engineering, Built Environment and Information Technology at SEGi University, Malaysia. She received her MSc (Quantity Surveying) from Heriot-Watt University and BSc (Hons) (Quantity Surveying) from Twintech International University College of Technology. 


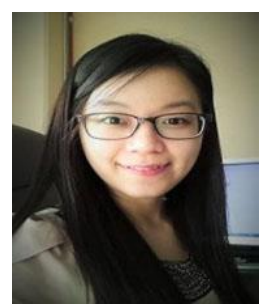

Siaw-Chuing Loo is a Senior Lecturer in Faculty of Built Environment at Universiti Malaya, Malaysia. She received her $\mathrm{PhD}, \mathrm{MSc}$ (Building), and Bachelor of Quantity Surveying (Hons) from Universiti Malaya. 